\title{
Dental Age Estimation based on Development Dental Atlas Assessment in a Child/Adolescent Population with Systemic
} Diseases

\section{Procjena dentalne dobi na temelju atlasa dentalnog razvoja u populaciji djece/adolescenata sa sistemskim bolestima}

\author{
${ }^{1}$ Faculty of Dental Medicine, University of Lisbon, Portugal \\ Stomatološki fakultet Sveučilišta u Lisabonu, Portugal Južni ogranak portugalskoga Nacionalnog instituta za pravnu medicinu i forenzičke \\ znanosti, Lisabon, Portugal \\ 2 Faculty of Dental Medicine, University of Ribeirão Preto, Brazil. Undergraduate Student, Dental Medicine. \\ Stomatološki fakultet Sveučilišta Ribeirão Preto, Brazil Student preddiplomskog studija dentalne medicine. \\ ${ }^{3}$ Forensic Odontology, University of Ribeirão Preto, Brazil. \\ Forenzička odntologija Sveučilišta Ribeirão Preto, Brazil \\ ${ }^{4}$ Department of Mathematics, School of Technology and Management, Polytechnic Institute of Leiria, Portugal \\ Odjel za matematiku Škole za tehnologiju i menadžment Politehničkog instituta Leiria, Portugal
}

\section{Abstract}

Background: Forensic estimation of chronological age has played an increasingly important role as part of cadaver identification, and also in living individuals due to the phenomenon of immigration and sexual abuse of undocumented trafficked children. Objective: This research aimed to validate the already used dental mineralization and eruption atlas in normal children and adolescent population in estimating chronological age in a young population, particularly those with special needs, majority of them with systemic diseases. Participants and Setting: A sample of 163 orthopantomograms from two independent medical institutions was collected from 133 patients aged between 4 and 23 years. Method: The orthopantomograms were divided into two groups, 95 from patients with systemic pathologies that have repercussions on dental development and 68 with systemic pathologies without dental repercussions. Dental ages were estimated by the London Atlas using the left side and then independently the right side of the maxilla. The intraobserver and interobserver agreements were evaluated. The difference between dental age estimates and the chronological age and its absolute value were calculated and analyzed.Results: Statistically significant differences were found between estimates and chronological age, revealing a general prevalence for underestimation; except for those under the age of 12. Nevertheless, the underestimation in individuals under the age of 16 was not significant (with an average of less than one month), while the underestimation was significant for persons who were at least 16 years old (with an average over 26 months). Furthermore, for those persons with systemic diseases with dental repercussions a greater error in underestimation was obtained, which indicates that the midpoint values should be reassessed in persons with Down's syndrome, chromosomal alterations, syndromes and central nervous system disorders. Conclusions: This atlas can be potentially used as a tool for age estimation in a population with special needs and, also, in a population with systemic diseases, but we suggest further studies with larger international samples to create adequate atlases for all the required scenarios, mainly, diagrams for people with systemic diseases who are over the age of 16.
Received: October 8, 2019

Accepted: December 1, 2019

Address for correspondence Cristiana Palmela Pereira University of Lisbon Faculty of Dental Medicine Rua Professora Teresa Ambrósio, 1600-277 Lisboa, Portugal. cristiana.pereira@fmd.ul.pt

\section{Introduction}

In Forensic Sciences the estimation of chronological age has achieved an important role in forensic cases, not only in the process of cadaver identification. Namely, its importance and use in living individuals has also expanded in recent years, particularly due to the increasing phenomenon of immigration and sexual abuse of undocumented trafficked children $(1,2,3,4)$.
Uvod

U forenzičkim znanostima procjena kronološke dobi vrlo je važna i to ne samo u procesu prepoznavanja trupala. Naime, njezina je važnost posljednjih godina sve veća i kad je riječ o živim jedinkama, posebno zbog sve izraženijeg fenomena imigracije i trgovine ljudima bez dokumenata $(1,2,3,4)$.

Kronološka i biološka dob različiti su pojmovi, pri čemu se prva odnosi na vrijeme proteklo od rođenja mjereno u je- 
Chronological aging and biological aging are quite distinct concepts; the first one relates to the time elapsed since birth, and is measured in the units of time, extending to any point in time being used in a research and development monitoring as a legal measure of grouping individuals. The second, apart from other methods, refers to bone age, dental age and sexual age; In this case, the age is being estimated from the analysis of the maturation of one or more tissues or organs, such as bones or teeth, wherein maturation is assessed by the occurrence of an event or a sequence of irreversible events which are subsequently compared to normal standards $(5,6,7)$.

Dental development has several structural changes throughout life that make them good age indicators, and their mineralization and eruption are less affected by endocrine, environmental and nutritional changes, compared to bone markers, thus being extremely significant and fundamental in estimating age $(8,9,10,11)$.

Dental radiographs have been used for dental age estimation, proving to be an important source of information for Forensic Dentistry (12). Several methods, developed by different authors, have used periapical radiographs and/or orthopantomograms (OPGs), which are less expensive and faster compared to other methods $(10,13,14)$, but no method is $100 \%$ accurate mainly due to the systematic errors inherent to each method, the intra - and inter - observer variability (15) and factors related to ethnicity, socioeconomic level and pathological alterations, leading to situations of overestimation or underestimation $(6,16,17)$.

The difficulty arises when it comes to individuals with special needs, be it due to a syndrome or other conditions which may modify the expected dental development (18, 19). Chromosomal disorders and syndromes arising from numerical and structural defects of chromosomes often include manifestations affecting the craniofacial region, and many of these chromosomal and multifactorial disorders have characteristic oral manifestations, such as multiple ageneses and a late eruption of the deciduous dentition and permanent dentition $(6,18,20,21,22)$. The prevalence of births with chromosomal anomalies was 34.8 cases/10000 births, Down's syndrome being the group of congenital anomalies with a higher prevalence (19.6 cases/10000 births) $(23,24)$.

There are several methods of age estimation through the use of radiography, including the Atlas of London (25) which has already been applied to several populations, including the Portuguese population $(16,26)$, in the normal population with no systemic diseases. In this way, the objective of this research is to validate the London Atlas by means of panoramic radiographs, in a population with both physical and mental congenital deficiencies in order to be able to estimate chronological age in a forensic context, mainly in living children and young adults.

The main objective of this research was to estimate the chronological age of a population with special needs at the University of Lisbon in two different institutions, through the application of the London Atlas based on the analysis of orthopantomograms with the scope of a future application in the forensic field. Experimental hypotheses were established, where the null hypothesis revealed the absence of statistically dinicama vremena i proteže se do bilo kojeg trenutka koji se koristi u praćenju istraživanja i razvoja kao pravna mjera grupiranja pojedinaca. Druga se odnosi na koštanu, zubnu i spolnu dob, a procjenjuje se analizom sazrijevanja jednoga ili više tkiva ili organa, poput kostiju ili zuba, pri čemu se sazrijevanje ocjenjuje događajem ili nizom nepovratnih događaja koji se uspoređuju s normalnim standardima $(5,6,7)$.

U razvoju zuba tijekom života nekoliko je strukturnih promjena pa su oni dobri pokazatelji dobi, a na njihovu mineralizaciju i erupciju manje utječu endokrine, ekološke i prehrambene promjene u usporedbi s koštanim markerima. Dakle, razvoj zuba iznimno je važan u procjeni dobi $(8,9$, $10,11)$.

Stomatološke rendgenske snimke korištene za procjenu starosti zuba pokazale su se važnim izvorom informacija u forenzičkoj stomatologiji (12). Nekoliko metoda koje su predložili različiti autori temelje se na periapikalnim snimkama i/ ili ortopantomogramima (OPG) koji su jeftiniji i brži u usporedbi s drugim metodama $(10,13,14)$, ali nijedna nije $100 \%$ točna, uglavnom zbog sustavnih pogrešaka svojstvenih svakoj od njih, varijabilnosti unutar ispitivača i između njih (15) i čimbenika povezanih s etničkom pripadnošću, socijalno-ekonomskim statusom i patološkim promjenama, što rezultira precijenjenom ili podcijenjenom dobi $(6,16,17)$.

Poteškoće se pojavljuju kod pojedinaca $s$ posebnim potrebama, bilo da je riječ o sindromu ili drugim stanjima koja mogu izmijeniti očekivani dentalni razvoj $(18,19)$. Kromosomski poremećaji i sindromi nastali zbog numeričkih i strukturnih oštećenja kromosoma često obuhvaćaju manifestacije koje utječu na kraniofacijalnu regiju, a mnogi od kromosomskih i multifaktorskih poremećaja imaju karakteristične oralne manifestacije poput multiple ageneze i kasne erupcije mliječnih i trajnih zuba $(6,18,20,21,22)$. Prevalencija osoba rođenih $s$ kromosomskim anomalijama iznosila je 34,8 slučajeva na 10000 rođenja, a Downov sindrom skupina je urođenih anomalija $s$ većom prevalencijom $(19,6$ slučajeva na 10000 rođenja) $(23,24)$.

Nekoliko je metoda za procjenu dobi s pomoću radioloških nalaza, uključujući i Londonov atlas (25) koji je već primijenjen na nekoliko populacija, pa i na portugalsko stanovništvo $(16,26)$ u normalnoj populaciji bez sistemskih bolesti. Zato je cilj ovog istraživanja bio validirati Londonov atlas s pomoću panoramskih rendgenskih snimki u populaciji koja ima prirođene fizičke i psihičke nedostatke, kako bi se u forenzičkim okolnostima mogla procijeniti kronološka dob, uglavnom žive djece i mladih odraslih.

Glavni cilj ovog istraživanja bio je procijeniti kronološku dob populacije s posebnim potrebama na Lisabonskom sveučilištu u dvjema različitim institucijama i to primjenom Londonova atlasa temeljenog na analizi ortopantomograma. Postavljene su i eksperimentalne hipoteze, pa tako nulta hipoteza pretpostavlja nedostatak statistički značajnih razlika, a alternativna hipoteza postojanje statistički značajnih razlika. Zato su predložene sljedeće eksperimentalne hipoteze:

1) razlika između kronološke dobi i procijenjene dentalne dobi (procjena točnosti)

2) razlika u točnosti procjena između mlađih i starijih od 16 godina 
significant differences and the alternative hypothesis revealed the existence of statistically significant differences. Hence, the following experimental hypotheses were formulated:

1) Difference between chronological age and estimated dental age (assessment of the accuracy of estimates)

2) Difference in the accuracy of estimates between under and over 16 years of age.

As secondary goals, the following experimental hypotheses were established:

1) Difference in the accuracy between left side and right side estimates

2) Difference in the accuracy of estimates between genders

3) Difference in the accuracy of estimates between patients with systemic diseases with dental repercussions and those without dental repercussions.

\section{Materials and methods}

The clinical records for this research from the two institutions were collected from the Pre-Graduation Clinics in Dental Medicine, Oral Hygiene, in the Department of PostGraduation in Orthodontics and in the Service of Stomatology of Centro Hospitalar Lisboa Norte (HSM), both institutions of the University of Lisbon. The population was selected through a systematic sampling process and it comprised a minimum of 100 subjects of both genders, aged between 2.5 and 23 years, all with an OPG. The experimental protocol was evaluated and approved by the Ethics Committee of Faculty of Dental Medicine University of Lisbon (FMDUL), Figure 1.

The included dental parameters refer to the presence of healthy teeth that are in the period of mineralization and eruption, since the identification parameters relate to the ages between 2.5 years and 23 years. Conversely, the exclusion dental parameters refer to the presence of extensive dental caries lesions, direct or indirect restorations, trauma or dental fracture, periodontal disease, dental rotations, dental rehabilitation with fixed prosthesis, orthodontic appliance, internal or external dental resorption, calcification, pulp fibrosis or periapical pathology and endodontic treatment. The exclusion parameters refer to the presence of dental overlaps, which interferes with the application of the London Atlas and distortion on the radiograph.

For this study a sample of 163 orthopantomograms (76 female and 87 male) from two institutions, FMDUL (112 OPGs) and HSM (51 OPGs), were collected from $133 \mathrm{pa-}$ tients ( 60 females and 73 males) aged between 4 and 23 years (Figure 2). Two dental age estimates were computed by the London Atlas for each orthopantomogram, first using only the left side (LS) of the maxilla and then using only the right side (RS) of the maxilla. Those two estimates were performed independently to avoid one estimate influence another. The intraobserver and interobserver agreements were evaluated using the intra-class correlation coefficient (ICC) (27). For intraobserver agreement, a reanalysis of $10 \%(n=17)$ of the observations of the total sample was conducted after the period of 3 months. For the interobserver agreement, all estimates were performed independently by two observers. The
Kao sekundarni ciljevi postavljene su sljedeće eksperimentalne hipoteze:

1) razlika u točnosti procjene na lijevoj i desnoj strani

2) razlika u točnosti procjene između spolova

3) razlika u točnosti procjene između pacijenata sa sistemskim bolestima s posljedicama i bez posljedica na zube.

\section{Materijali i metode}

Za ovo istraživanje prikupljeni su klinički zapisi iz dviju institucija - Klinike za dentalnu medicinu, Odjela za poslijediplomske studije i Službe za dentalnu medicinu Bolničkoga centra Lisboa Norte (HSM-a). Obje djeluju u sklopu Sveučilišta u Lisabonu. Populacija je odabrana sustavnim postupkom uzorkovanja i sastojala se od najmanje 100 slučajeva pacijenata obaju spolova u dobi između 2, 5 i 23 godine i svi su imali OPG. Eksperimentalni protokol ocijenilo je i odobrilo Etičko povjerenstvo Stomatološkog fakulteta Sveučilišta u Lisabonu (FMDUL-a), slika 1.

Parametri za sudjelovanje odnosili su se na prisutnost zdravih zuba u razdoblju mineralizacije i erupcije, a identifikacijski parametri na dob između 2,5 i 23 godine. Parametri za isključivanje bili su opsežne karijesne lezije, direktne ili indirektne restauracije, trauma ili fraktura zuba, parodontna bolest, rotacije zuba, fiksnoprotetički nadomjestci, ortodontski aparat, unutarnja ili vanjska zubna resorpcija, kalcifikacija, fibroza pulpe ili periapikalna patologija i endodontsko liječenje. Radiografski parametri za isključivanje odnosili su se na preklapanja koja su ometala primjenu Londonova atlasa i izobličenja na snimci.

$\mathrm{Za}$ ovo istraživanje prikupljen je uzorak od 163 ortopantomograma (76 od djevojčica i djevojaka i 87 od dječaka i mladića) iz dviju ustanova - FMDUL-a (112 OPG-a) i HSM-a (51 OPG), od 133 pacijenta (60 djevojčica i djevojaka i 73 dječaka i mladića) u dobi između 4 i 23 godine (slika 2.). Dentalna dob izračunata je s pomoću Londonova atlasa za svaki ortopantomogram, najprije samo na lijevoj strani (LS-u) maksile, a zatim na njezinoj desnoj strani (DS-u). Te dvije procjene obavljene su neovisno tako da jedna nije utjecala na drugu. Podudarnost unutar ispitivača i između njih ocijenjena je korištenjem interklasnog koeficijenta korelacije (ICC-a) (27). Za podudarnost unutar ispitivača provedena je ponovna analiza $10 \%(\mathrm{n}=17)$ slučajeva od ukupnog uzorka nakon razdoblja od tri mjeseca. Za podudarnost između ispitivača, sve su procjene neovisno obavila dva ispitivača. Usporedba između procjene dobi na desnoj i lijevoj strani maksile obavljena je primjenom varijabli Dif_Right_Left (razlika između procijenjene dobi na temelju DS-a i procijenjene dobi na temelju LS-a u mjesecima) i Abs_Dif_Right_Left 
comparison between the use of the right side and left side of the maxilla for age estimation was performed using the variables Dif_Right_Left (difference between the estimated age based on the RS and the estimated age based on the LS, in months) and Abs_ Dif_Right_Left (absolute value of Dif_ Right_Left). The variables Dif_Right_Real (difference in months between the estimated age based on the RS and the chronological age) and Abs__Dif_Right_Real (absolute value of Dif_Right_Real) were computed to assess the accuracy of the estimates by the London Atlas using the RS. Likewise, for the LS estimates, the variables Dif_Left_Real (difference in months between the estimated age based on the LS and the chronological age) and Abs_Dif_Left_Real (absolute value Dif_Left_Real) were computed. Since the t-test should only be used in variables with normal distribution (which has not proven to be the case in this research due to the rejection of the null hypothesis in the application of the KolmogorovSmirnov test in all variables), the Wilcoxon's non-parametric test was applied to compare the medians.

\section{Results}

\section{Intraobserver and interobserver agreements}

The intra-observer ICC value was 0.956 and 0.977 for the RS and LS (Figure 3), respectively, which indicates an excellent agreement, where the $95 \%$ confidence interval ranged between 0.886 and 0.984 (RS) and between 0.938 and 0.991 (LS). In the interobserver reliability, ICC for the RS is 0.923 and for the LS was 0.927 (Figure 4), with a 95 per cent confidence interval ranging between 0.895 and 0.944 (RS) and 0.9 and 0.947 (LS). These values correspond to an almost perfect agreement between the observers, with no problem at the level of the interobserver analysis. It should be noted that in some cases there were a few discrepancies between the observers'estimates. Nevertheless, in most of the cases, 116 $(73.9 \%)$ on the RS and $121(77.6 \%)$ on the LS, the difference was at most 12 months. Moreover, the mean difference between the estimates from the two observers for the right (as well as for the left) side was 4 months, revealing concordant results between the observers.

\section{Right side versus left side}

The difference between the two estimates was on average 0.07 months. However, in one individual the difference between the two estimates was 36 months; in 7 individuals the difference between the two estimates was 24 months (in 3 the right estimate was higher than the left and the other 4 the opposite); in 40 individuals it was 12 months (in 23 the right estimate was higher than the left and in the remaining 17 the opposite was the case) and in the remaining 115 cases $(70.6 \%$ of the sample) the estimates were identical. In the application of the Wilcoxon non-parametric test for comparison of medians in related samples, the test p-value was 0.864 and, therefore, there is no evidence that the median of the two estimates is different. This analysis seems to illustrate that there are no significant differences between the two estimates by right versus left sides of the maxilla in a population with systemic diseases. (apsolutna vrijednost od Dif_Right_Lefta). Varijable Dif_ Right_Real (razlika u mjesecima između procijenjene dobi na temelju DS-a i kronološke dobi) i Abs_ Dif_Right_Real (apsolutna vrijednost Dif_Right_Reala) izračunate su za procjenu točnosti procjene s pomoću Londonova atlasa na DS-u. Analogno, za procjene LS-a izračunate su varijable za Dif_Left_Real (razlika u mjesecima između procijenjene dobi na temelju LS-a i kronološke dobi) i Abs_Dif_Left_Real (apsolutna vrijednost Dif_Left_Reala). Budući da se t-test treba upotrijebiti samo za varijable s normalnom distribucijom (što nije slučaj zbog odbacivanja nulte hipoteze u primjeni Kolmogorov-Smirnovljeva testa u svim varijablama), neparametrijski Wilcoxonov test primijenjen je za usporedbu medijana.

\section{Rezultati}

\section{Podudarnost unutar i između ispitivača}

ICC vrijednost unutar ispitivača bila je 0,956 i $0,977 \mathrm{za}$ DS i LS (slika 3.), što upućuje na dobru podudarnost jer se interval pouzdanosti od $95 \%$ kreće između 0,886 i 0,984 (DS) te između 0,938 i 0,991 (LS). Kad je riječ o podudarnosti između promatrača ICC-a za DS, iznosio je 0,923 , a za LS 0,927 (slika 4.), s intervalom pouzdanosti od $95 \%$ u rasponu između 0,895 i 0,944 (DS), te 0,9 i 0,947 (LS). Te vrijednosti odgovarale su gotovo savršenoj podudarnosti između promatrača, bez problema na razini analize između promatrača. Treba napomenuti da u nekim slučajevima postoji nekoliko odstupanja između procjena promatrača. Ipak, u većini slučajeva - $116(73,9 \%)$ na DS-u i $121(77,6 \%)$ na LS-u razlika je bila najviše 12 mjeseci. Štoviše, prosječna razlika između procjena dvaju promatrača za desnu (i za lijevu) stranu iznosila je četiri mjeseca, otkrivajući podudarne rezultate između promatrača.

\section{Desna strana nasuprot lijevoj strani}

Razlika između dviju procjena bila je u prosjeku 0,07 mjeseci. No kod jednog ispitanika bila je 36 mjeseci, kod njih 7 iznosila je 24 mjeseca (u 3 slučaja je procjena desno bila veća nego lijevo, a kod ostala 4 suprotna), kod 40 ispitanika razlika je bila 12 mjeseci (kod 23 je desno procjena bila veća nego lijevo, kod ostalih 17 bilo je suprotno), a u ostalih 115 slučajeva (70,6 \% uzorka) procjene su bile jednake. Primjenom Wilcoxonova neparametrijskog testa za usporedbu medijana u povezanim uzorcima, p-vrijednost je bila $0,864 \mathrm{i}$ zato ne postoje dokazi da je medijan dviju procjena različit. Čini se da ta analiza pokazuje kako nema značajne razlike između procjene na desnoj i lijevoj strani maksile u populaciji sa sistemskim bolestima. 


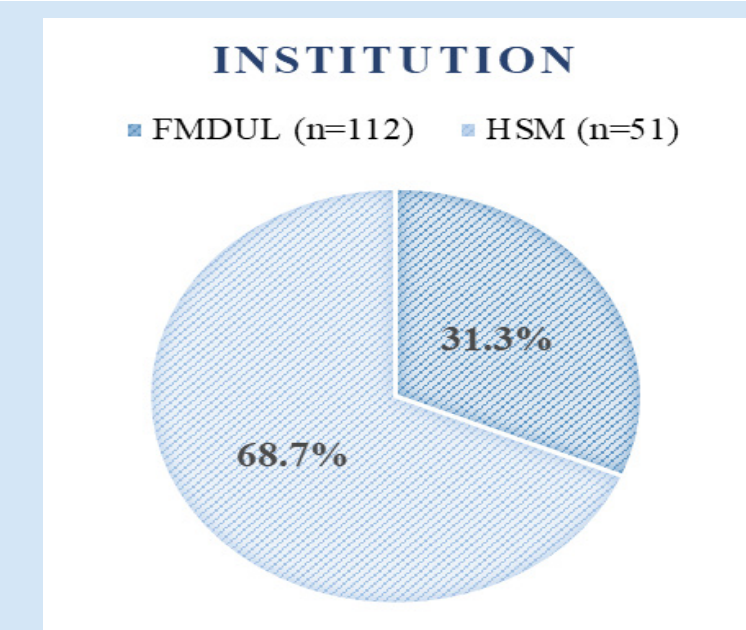

Figure 1 Sample distribution by institution

Slika 1. Distribucija uzorka prema institucijama

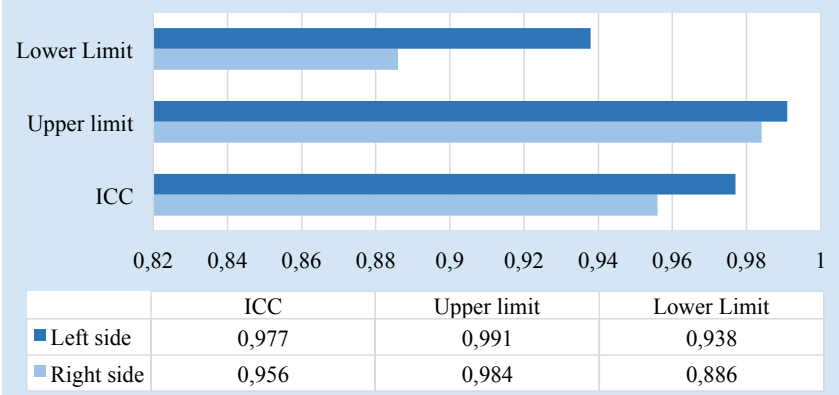

Figure 3 Intraobserver agreement

Slika 3. Podudarnost unutar ispitanika

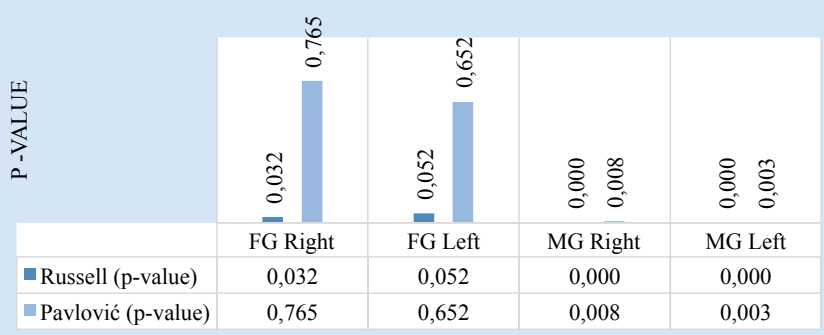

Figure 5 Differences between genders

Slika 5. Razlike između spolova

\begin{tabular}{|c|c|c|c|}
\hline 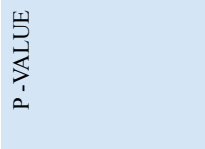 & 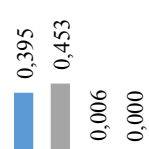 & 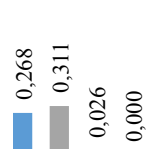 & 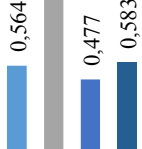 \\
\hline & Right vs Real & Left vs Real & Righ vs Left \\
\hline - Under 6 years & 0,395 & 0,268 & 0,564 \\
\hline $7-12$ years & 0,453 & 0,311 & 1,000 \\
\hline $13-16$ years & 0,006 & 0,026 & 0,477 \\
\hline - At least 17 years & 0,000 & 0,000 & 0,583 \\
\hline
\end{tabular}

Figure 7 Differences between different age groups

Slika 7. Razlike između dobnih skupina

\section{GENDER}

$\approx$ Male $\mathrm{n}=87 \approx$ Female $\mathrm{n}=76$

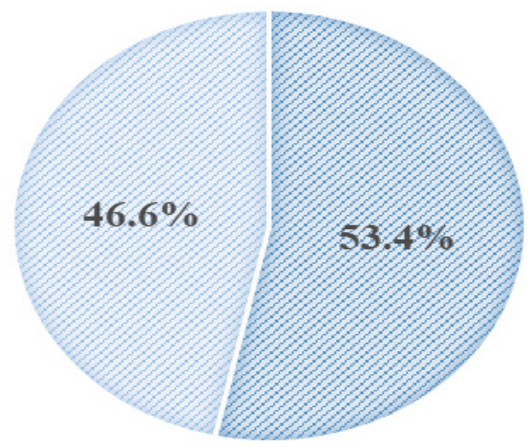

Figure 2 Sample distributions by gender

Slika 2. Distribucija uzorka prema spolu

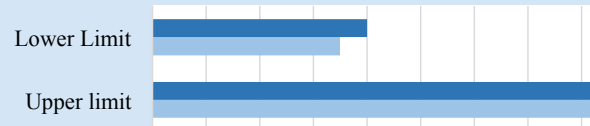

ICC

$\begin{array}{lllllllllll}0,86 & 0,87 & 0,88 & 0,89 & 0,9 & 0,91 & 0,92 & 0,93 & 0,94 & 0,95 & 0,96\end{array}$

\begin{tabular}{|l|c|c|c|}
\hline - Left side M vs L & ICC & Upper limit & Lower Limit \\
\hline - Right side M vs L & 0,927 & 0,947 & 0,900 \\
\hline
\end{tabular}

Figure 4 Interobserver agreement

Slika 4. Podudarnost između ispitanika

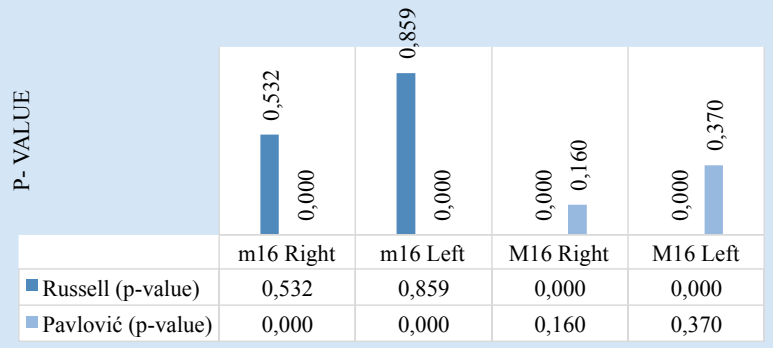

Figure 6 Differences between under and over 16 years of age Slika 6. Razlike između dobnih skupina mlađih i starijih 16 godina 


\section{Accuracy of estimates}

The underestimation using the London Atlas, by the left side was on average 11.64 months. The observed maximum underestimation error was 123 months. The observed maximum error of overestimation was 67 months and the average error of estimation (in absolute value) was about 22 months. The p-value of the Wilcoxon's non-parametric test for related samples, that is, comparison of the right side estimates with the real age was equal to 0.000 . Therefore, there was evidence that the median is different.

The underestimation using the London Atlas by the left side is on average 11.71 months. The observed maximum underestimation error was 123 months. The maximum error of overestimation was 67 months and the average error of estimation (in absolute value) was about 22.31 months. In the application of the Wilcoxon non-parametric test for comparison of medians in related samples, the value of the $\mathrm{p}$-value was 0.000 . Thus, there is evidence that the median of the left side estimates is different from the median of chronological age.

Hence, it seems that the estimates obtained on both sides are biased, i.e., a systematic error was made when using this estimation procedure.

\section{Gender}

When splitting the data in gender groups (FG versus $\mathrm{MG}$ ) there were $87 \mathrm{MG}$ and $76 \mathrm{FG}$. The results for both genders showed issues in the accuracy of estimates (Figure 3), with significant differences between estimates and chronological ages, although one p-value was slightly higher than $5 \%$. Moreover, no significant differences were found in the non-parametric test to compare MG with the FG: p-values = 0.133 for Dif_Right_Real (MG versus FG); p-value $=0.073$ for Dif_Left_Real (MG versus FG); and p-value $=0.563$ for Dif_Right_Left (MG versus FG). Therefore, the results reveal no significant differences between MG and FG (Figure 5).

\section{Age Groups}

When splitting the data into age groups, substantial differences were observed between the groups of under the age of 16 (m16) with 93 individuals and at least 16-years of age (M16) with 70 individuals. There was an average error of underestimation of 0.75 months (RS) and 0.37 months (LS) in m16 and 26.10 months (RS) and 26.79 months (LS) on M16. Thus, while m16 reveals no significant differences between estimates and chronological ages, M16 clearly denotes biased estimates (Figure 6) in the application of non-parametric tests. Moreover, the London Atlas has proven to be a good method to identify patients under the age of 16 .

Thus, in this study, the success rate for properly classifying children under 16 years of age (those who must be protected) was $96.8 \%$ (right and left), and a considerable success rate of $75.7 \%$ for properly classified on the $\mathrm{RS}$ and $74.3 \%$ on the LS for individuals of at least 16 years of age.

When the data were separated into the subgroups of those up to 6 years, between 7 and 12 years, between 13 and 16 years, and at least 17 year-olds, the results of the age estimation were different. For those under 6 years of age (overestimation, on average, of 4.57 months on RS and 2.86 months

\section{Točnost procjena}

Primjenom Londonova atlasa na lijevoj strani dob je $\mathrm{u}$ prosjeku podcijenjena za 11,64 mjeseca. Maksimalna pogreška podcjenjivanja iznosila je 123 mjeseca, maksimalna pogreška precjenjivanja dobi iznosila je 67 mjeseci, a prosječna pogreška procjene (u apsolutnoj vrijednosti) oko 22 mjeseca. P-vrijednost Wilcoxonova neparametrijskog testa za usporedbu procijenjene i stvarne dobi iznosila je 0,000. Tako je dokazano da je medijan različit.

Primjenom Londonova atlasa na lijevoj strani dob je $\mathrm{u}$ prosjeku podcijenjena za 11,71 mjesec, maksimalna pogreška podcjenjivanja dobi iznosila je 123 mjeseca, maksimalna pogreška precjenjivanja dobi bila je 67 mjeseci, a prosječna pogreška procjene (u apsolutnoj vrijednosti) oko 22,31 mjesec. Primjenom Wilcoxonova neparametrijskog testa za usporedbu medijana u povezanim uzorcima, $\mathrm{p}$-vrijednost iznosila je 0,000 . Dakle, postoje dokazi da se medijan procjene na lijevoj strani razlikuje od medijana kronološke dobi.

Stoga se čini da su procjene dobivene na objema stranama pristrane, tj. da je učinjena sustavna pogreška u postupku procjene.

\section{Spol}

Podjelom podataka na spolne skupine ( $\check{Z}$ prema $M)$ bilo je 87 dječaka i mladića i 76 djevojčica i djevojaka. U oba spola ustanovljeni su problemi s točnošću procjene (grafikon 3.) sa značajnim razlikama između procijenjene i kronološke dobi, iako je p-vrijednost nešto viša od $5 \%$. Štoviše, nisu prikazane značajne razlike u neparametrijskim testovima za usporedbu muškoga i ženskoga spola: p-vrijednosti $=0,133$ za Dif_Right_Real (M prema Ž; p-vrijednost $=0,073$ za Dif_ Left_Real (M prema Z); i p-vrijednost $=0,563$ za Dif_Right Left (M u odnosu prema $\check{Z}$ ). Pritom rezultati nisu pokazali značajne razlike između muškoga i ženskoga roda (slika 5.).

\section{Dobne skupine}

Podjelom podataka na dobne skupine uočene su znatne razlike između skupine mladih od 16 godina (m 16) s 93 ispitanika i starijih od 16 godina (M 16) sa 70 ispitanika. Postojala je prosječna pogreška podcjenjivanja od 0,75 mjeseci (DS) i 0,37 mjeseci (LS) u skupini m 16 i 26,10 mjeseci (RS) i 26,79 mjeseci (LS) u skupini M 16. Dakle, dok u skupini m 16 primjenom neparametrijskih testova nisu ustanovljene značajne razlike između procijenjene i kronološke dobi, u skupini M 16 uočene su pristrane procjene (slika 6.). Štoviše, Londonov atlas pokazao se kao dobra metoda za prepoznavanje pacijenata mladih od 16 godina. Dakle, u ovom istraživanju kod 96,8 \% (desna i lijeva strana) djece mlađe od 16 godina uspješno je procijenjena dob (one koja moraju biti zaštićena), a u skupini starijoj od 16 godina $75,7 \%$ na desnoj strani i 74,3\% na lijevoj strani.

Kada se podatci razdvoje u podskupine do 6 godina, između 7 i 12 godina, između 13 i 16 godina i najmanje 17 godina, također su zabilježeni različiti rezultati u procjeni dobi. Za mlađe od 6 godina (precjenjivanje u prosjeku za 4,57 mjeseci na desnoj strani i 2,86 mjeseci na lijevoj strani) i 7 do 12 godina (precjenjivanje u prosjeku za 2,02 mjeseca na objema 
Table 1 Distribution of the sample by institution, gender and chronological age

Tablica 1. Distribucija uzorka prema instituciji, spolu i kronološkoj dobi

\begin{tabular}{|c|c|c|c|c|}
\hline & & \multirow{2}{*}{\multicolumn{2}{|c|}{$\begin{array}{c}\text { HSM } \\
\text { Gender } \bullet \text { Spol }\end{array}$}} & \multirow{4}{*}{$\begin{array}{c}\text { FMDUL } \\
\text { Gender } \bullet \text { Spol } \\
\text { Male } \bullet \text { Muški } \\
\text { Score } \bullet \text { Rezultat }\end{array}$} \\
\hline & & & & \\
\hline & & \multicolumn{2}{|c|}{ Male • Muški } & \\
\hline & & Score $\bullet$ Rezultat & Score $\bullet$ Rezultat & \\
\hline \multirow[t]{20}{*}{ Chronological age $\bullet$ Kronološka dob } & 4 & 0 & 0 & 1 \\
\hline & 5 & 1 & 0 & 1 \\
\hline & 6 & 0 & 0 & 2 \\
\hline & 7 & 1 & 2 & 0 \\
\hline & 8 & 5 & 0 & 1 \\
\hline & 9 & 0 & 1 & 3 \\
\hline & 10 & 2 & 3 & 8 \\
\hline & 11 & 3 & 3 & 2 \\
\hline & 12 & 1 & 1 & 3 \\
\hline & 13 & 7 & 0 & 1 \\
\hline & 14 & 2 & 2 & 2 \\
\hline & 15 & 1 & 1 & 2 \\
\hline & 16 & 2 & 1 & 4 \\
\hline & 17 & 1 & 2 & 5 \\
\hline & 18 & 1 & 1 & 4 \\
\hline & 19 & 1 & 2 & 4 \\
\hline & 20 & 0 & 1 & 5 \\
\hline & 21 & 0 & 0 & 4 \\
\hline & 22 & 2 & 0 & 5 \\
\hline & 23 & 0 & 1 & 0 \\
\hline
\end{tabular}

on LS) and the 7 to 12 years old (overestimation, on average, of 2.02 months on both sides) the results were not biased, i.e. the differences between estimates and chronological ages were not statistically significant. For those between 1316 years old (underestimation of on average 7.95 months on RS and 6.97 months on LS) and at least 17 years old (underestimation, on average, of 29.23 months on RS and 29.83 months on LS) the results were biased with a statistically significant underestimation error (Figure 7).

\section{Disease}

A division was made into a group where no repercussions in the mineralization and dental eruption were apparent and a group where dental repercussions were evident. The repercussions group was divided into several sub-groups where we divided the systemic diseases into Down's syndrome, chromosomic alterations, syndromes and central nervous system (Table 2). Comparing all of the six groups, in the non-parametric hypothesis tests, we reached the following conclusions: $\mathrm{p}$-value $=0.255$ (right versus real); $\mathrm{p}$-value $=0.579$ (left versus real); $\mathrm{p}$-value $=0.796$ (right versus left). When comparing the medians of the three variables under analysis, the results reveal no significant differences between the six groups.

Comparing the data from both groups (Table 3), we can verify that the average and the median of the difference between estimated and chronological age in the control group is much lower than in the group with dental repercussions, which implies that the estimates are less accurate in the group with dental repercussions, despite the minimum and the maximum estimation errors are higher in the control group. stranama), rezultati nisu bili pristrani, tj. razlike između procijenjene i kronološke dobi nisu bile statistički značajne. Za ispitanike između 13 i 16 godina (podcjenjivanje u prosjeku za 7,95 mjeseci na desnoj strani i 6,97 mjeseci na lijevoj strani) i najmanje 17 godina (podcjenjivanje u prosjeku za 29,23 mjeseca na desnoj strani i 29,83 mjeseca na desnoj strani) rezultati su bili pristrani, sa statistički značajnom pogreškom u podcjenjivanju (slika 7.).

\section{Bolesti}

Podjela je učinjena na skupinu u kojoj nisu bile vidjjive posljedice na mineralizaciju i erupciju zuba te na skupinu $s$ vidljivim posljedicama za zube. Skupina s posljedicama za zube podijeljena je u nekoliko podskupina. tako su sistemske bolesti razvrstane na Downov sindrom, kromosomske promjene, sindrome i bolesti središnjega živčanog sustava (tablica 2.). Nakon usporedbe svih šest skupina, na temelju neparametrijskih testova zaključeno je sljedeće: $\mathrm{p}$-vrijednost $=$ 0,255 (desna prema stvarnoj); p-vrijednost $=0,579$ (lijeva prema stvarnoj); $p$-vrijednost $=0,796$ (desna prema lijevoj). Kada su usporedeni medijani triju analiziranih varijabli, rezultati nisu pokazivali značajne razlike između šest skupina.

Uspoređujući podatke iz obiju skupina (tablica 3.), može se potvrditi da su prosjek i medijan razlike između procijenjene i kronološke dobi u kontrolnoj skupini mnogo niži negoli u skupini s posljedicama na zube, što upućuje na to da su procjene manje točne u skupini $s$ posljedicama na zube, unatoč tomu što su minimalne i maksimalne pogreške procjene veće u kontrolnoj skupini. Kad je riječ o razlikama između 


\begin{tabular}{|c|c|c|c|c|c|}
\hline \multirow[t]{15}{*}{$\begin{array}{l}\text { Down's } \\
\text { Syndrome • } \\
\text { Downov } \\
\text { sindrom }\end{array}$} & $\begin{array}{l}\text { Chromosomic } \\
\text { Alterations } \\
\text { Kromosomske } \\
\text { promjene }\end{array}$ & Syndromes $\bullet$ Sindromi & $\begin{array}{c}\text { Central Nervous } \\
\text { System } \bullet \\
\text { Središnji živčani sustav }\end{array}$ & Others $\bullet$ Ostalo & $\begin{array}{l}\text { Pathologies with no } \\
\text { dental symptoms } \\
\text { Patologije } s \text { dentalnim } \\
\text { simptomima }\end{array}$ \\
\hline & $\begin{array}{l}\text { Chromosome } 1 \text { deletion } \\
\text { - Delecija kromosoma } 1\end{array}$ & $\begin{array}{l}\text { Cornelia de Lange } \\
\text { syndrome } \bullet \text { De Langeov } \\
\text { sindrom }\end{array}$ & $\begin{array}{l}\text { Cerebral palsy } \bullet \\
\text { Cerebralna paraliza }\end{array}$ & $\begin{array}{l}\text { Arthrogryposis cognitive } \\
\text { deficits } \bullet \text { Artrogripoza } \\
\text { kognitivni deficit }\end{array}$ & $\begin{array}{l}21 \text { Alpha hydroxybase } \\
\text { deficiency } \bullet \text { Deficijencija } \\
21 \text { alfa hidroksibaze }\end{array}$ \\
\hline & $\begin{array}{l}\text { Chromosome } 1 \\
\text { alteration } \bullet \text { Alteracija } \\
\text { kromosoma } 1\end{array}$ & $\begin{array}{l}\text { De Charge syndrome } \\
\text { De Chargeov sindrom }\end{array}$ & $\begin{array}{l}\text { Development delay • } \\
\text { Kašnjenje u razvoju }\end{array}$ & $\begin{array}{l}\text { Asperger's } \bullet \text { Ašpergerov } \\
\text { sindrom }\end{array}$ & $\begin{array}{l}\text { Congenital cardiopathy } \\
\text { - Kongenitalna } \\
\text { kardiopatija }\end{array}$ \\
\hline & $\begin{array}{l}\text { Chromosome } 4 \\
\text { deficiency } \bullet \text { Deficijencija } \\
\text { kromosoma } 4\end{array}$ & $\begin{array}{l}\text { DiGeorge syndrome } \bullet \text { Di } \\
\text { Georgeov sindrom }\end{array}$ & $\begin{array}{l}\text { Global development } \\
\text { delay } \bullet \text { Generalizirano } \\
\text { kašnjenje u razvoju }\end{array}$ & Autism • Autizam & Epilepsy・Epilepsija \\
\hline & $\begin{array}{l}\text { Chromosome alteration } \\
\text { - Alteracija kromosoma }\end{array}$ & \begin{tabular}{|l} 
Dravet syndrome \\
Dravetov sindrom
\end{tabular} & $\begin{array}{l}\text { Embryopathy • } \\
\text { Embriopatija }\end{array}$ & $\begin{array}{l}\text { Cognitive impairment } \\
\text { Kognitivno oštećenje }\end{array}$ & $\begin{array}{l}\text { Hearing impairment • } \\
\text { Oštećenje sluha }\end{array}$ \\
\hline & $\begin{array}{l}\text { Deletion chromosome } \\
16 \bullet \text { Delecija } \\
\text { kromosoma } 16\end{array}$ & $\begin{array}{l}\text { Kabuki syndrome } \bullet \\
\text { Kabukijev sindrom }\end{array}$ & $\begin{array}{l}\text { Malformation of central } \\
\text { nervous System } \bullet \\
\text { Malformacija središnjega } \\
\text { živčanog sustava }\end{array}$ & Encephalitis $\bullet$ Encefalitis & $\begin{array}{l}\text { Hyperactivity } \\
\text { Hiperaktivnost }\end{array}$ \\
\hline & $\begin{array}{l}\text { Non-identified } \\
\text { chromosomal mutation } \\
\text { • Neidentificirana } \\
\text { mutacija kromosoma }\end{array}$ & $\begin{array}{l}\text { KGB syndrome } \bullet \mathrm{KGB} \\
\text { sindrom }\end{array}$ & $\begin{array}{l}\text { Mental retardation } \bullet \\
\text { Mentalna retardacija }\end{array}$ & $\begin{array}{l}\text { Encephalopathy } \\
\text { Encefalopatija }\end{array}$ & $\begin{array}{l}\text { Metabolic diseases } \\
\text { Metaboličke bolesti }\end{array}$ \\
\hline & & $\begin{array}{l}\text { Landau Kleffner } \\
\text { syndrome } \bullet \text { Landau- } \\
\text { Kleffnerov sindrom }\end{array}$ & $\begin{array}{l}\text { Microcephaly } \\
\text { Mikrocefalija }\end{array}$ & $\begin{array}{l}\text { Global cognitive deficit } \\
\text { Kognitivni deficit }\end{array}$ & $\begin{array}{l}\text { Muscular dystrophy } \\
\text { Mišićna distrofija }\end{array}$ \\
\hline & & $\begin{array}{l}\text { McCune syndrome } \bullet \text { Mc } \\
\text { Cuneov sindrom }\end{array}$ & $\begin{array}{l}\text { Neural impairment } \\
\text { Neuralna oštećenja }\end{array}$ & $\begin{array}{l}\text { Poliformative } \\
\text { hypotonic syndrome } \\
\text { - Poliformativni } \\
\text { hipotonični sindrom }\end{array}$ & $\begin{array}{l}\text { OTC deficiency • OTC } \\
\text { deficijencija }\end{array}$ \\
\hline & & $\begin{array}{l}\text { Prader Willi syndrome } \\
\text { Prader- Willijev sindrom }\end{array}$ & $\begin{array}{l}\text { Psychomotor retardation } \\
\text { - Psihomotorčko } \\
\text { zaostajanje }\end{array}$ & $\begin{array}{l}\text { Without a closed } \\
\text { diagnosis } \bullet \text { Bez dijagnoze }\end{array}$ & $\begin{array}{l}\text { Polymyositis • } \\
\text { Polimiozitis }\end{array}$ \\
\hline & & $\begin{array}{l}\text { Rett syndrome } \bullet \text { Rettov } \\
\text { sindrom }\end{array}$ & $\begin{array}{l}\text { Slight mental retardation } \\
\text { - Blaga mentalna } \\
\text { retardacija }\end{array}$ & & $\begin{array}{l}\text { Psychological immaturity } \\
\text { - Psihička nezrelost }\end{array}$ \\
\hline & & $\begin{array}{l}\text { Rubiten syndrome } \\
\text { Rubitenov sindrom }\end{array}$ & & & $\begin{array}{l}\text { Severe atopic eczema } \\
\text { Atopični ekcemi }\end{array}$ \\
\hline & & $\begin{array}{l}\text { Syndrome } 47 \cdot \text { Sindrom } \\
47\end{array}$ & & & $\begin{array}{l}\text { Skeletal side root } \\
\text { syndrome } \bullet \text { Koštane i } \\
\text { dentalne malformacije }\end{array}$ \\
\hline & & $\begin{array}{l}\text { Syndrome type } 1 \bullet \\
\text { Sindrom tipa } 1\end{array}$ & & & Spina bifida \\
\hline & & $\begin{array}{l}\text { Williams syndrome • } \\
\text { Williamsov sindrom }\end{array}$ & & & \\
\hline
\end{tabular}

As for the difference between RS and LS, there are no significant differences. The results of the comparison of these groups were the following: $\mathrm{p}$-value $=0.044$ (right versus real); $\mathrm{p}$-value $=0.076$ (left versus real); $\mathrm{p}$-value $=0.630$ (right versus left). The results show a discrepancy in the estimation of right versus real and left versus real which prevents us from making a full conclusion as to whether exits significant differences in estimates accuracy between these two groups. One of the pvalue is higher than the $5 \%$ significance; therefore, based only on the p-value, the null hypothesis should not be rejected for left versus real, but is rejected for right versus real. Thus, it seems that we are on the threshold of rejecting and not rejecting the null hypothesis, because it does not detect differences between the left and right estimates, nor between the left es-
DS-a i LS-a, one nisu bile statistički značajne. Rezultati usporedbe tih skupina bili su sljedeći: $\mathrm{p}$-vrijednost $=0,044$ (desna prema stvarnoj); p-vrijednost $=0,076$ (lijeva prema stvarnoj); $\mathrm{p}$-vrijednost $=0,630$ (desna prema lijevoj). Rezultati pokazuju neusklađenost u procjeni na desnoj strani prema stvarnoj dobi i na lijevoj strani prema stvarnoj dobi, što sprječava donošenje cjelovitog zaključka o tome postoje li značajne razlike u točnosti procjene između tih dviju skupina. Jedna od p-vrijednosti bila je veća od 5-postotne vrijednosti, pa se nulta hipoteza ne smije odbaciti za lijevu stranu u odnosu prema stvarnoj dobi, nego samo za desnu stranu u odnosu prema stvarnoj dobi. Zato se čini da smo na pragu odbacivanja i prihvaćanja nulte hipoteze jer nisu ustanovljene razlike između procjena na lijevoj i desnoj strani, ni između procjene 
timates and the real values, but detects significant differences between the right estimates and the real values.

\section{Discussion}

The obtained intraobserver ICC values are slightly higher than in AlQahtani (0.879) (23) and Cesário et al (0.925) (16) but lower than in Pavlović et al (26) (0.998 and 0.997 for RS and LS, correspondingly). As for Pinchi et al (6) they reported a $93 \%$ agreement.

Regarding the interobserver reliability, the obtained values are in concordance with findings of Pinchi et al (6) which have an interobserver agreement of $90 \%$.

One of the main goals of this work was to analyze whether there are noteworthy differences between chronological and estimated age. The Atlas of AlQahtani (25) was selected as the method of estimation since, compared with other atlas methods, it is the one with the best results, as it has showed no bias $(\mathrm{p}=0.720)$ and correctly estimated $53 \%$ of the cases in the original thesis $(16,25)$.

In this study, the results reveal that there were some errors in the estimates for both RS and LS. For comparison purposes, the results from the study of Cesário et al (16), Pavlović et al (26) and Pinchi et al (6) were used. The performance test showed a statistically significant difference between age estimation and chronological age. It seems that the estimates obtained on both sides are biased, i.e., a systematic error was made (Right: author $\mathrm{p}=0.000$; Pavlović $\mathrm{p}=0.104$; Left: author $\mathrm{p}=0.000$; Pavlović $\mathrm{p}=0.052$ ). Thus, these results are not consistent with Pavlović et al (26), knowing that the main difference between these studies was the population at hand, i.e. patients with syndromes. Furthermore, the error was consistent between sides and no significant difference between age estimation using the RS or the LS (author $\mathrm{p}=0.864$; Pavlović $\mathrm{p}=0.066$ ) was perceived. For the author the maximum underestimation was 123 months, (Pavlović 91 months), while the maximum overestimation was 67 months (Pavlović 79 months) (26).

Another main goal was to analyze if there were any differences between those under or at least 16 years of age ( 16 vs M16). In both age groups there was a tendency to underestimate in this study, although AlQahtani (25) and Cesário et al (16) came to the opposite conclusion. The average underestimation error in the age group $\mathrm{m} 16$ was much lower than in the opposite age group M16 (0.75 months right and 0.37 months left for $\mathrm{m} 16$ and 26.10 months right and 26.79 months left for M16), although the difference between sides was almost negligible (6). Furthermore, the results obtained revealed that there was no evidence that the median of the estimates is different from the median of chronological age in the under 16 years of age group (right: author $\mathrm{p}=0.532$; Pavlović $\mathrm{p}=0.000$; left: author $\mathrm{p}=0.859$; Pavlović $\mathrm{p}=0.000$ ) while in the $\mathrm{M} 16$ group the difference seems to be significant (right: author $\mathrm{p}=0.000$; Pavlović $\mathrm{p}=0.105$; left: author $\mathrm{p}=0.000$; Pavlović $\mathrm{p}=0.161$ ). Hence, authors obtained opposite results for these age groups. This can be explained by the fact that populations examined are distinct, and when patients with (more likely to have) slower tooth development are included, estimates should further na lijevoj strani i stvarne vrijednosti, ali su postojale značajne razlike između procjene na desnoj strani i stvarne vrijednosti.

\section{Rasprava}

Dobivene ICC vrijednosti unutar promatrača bile su nešto veće negoli kod Al-Qahtanija $(0,879)(23)$ i Cesárija i suradnika $(0,925)(16)$, ali niže negoli kod Pavlovića i suradnika (26) $(0,998$ i 0,997 za RS i LS). Pinchi i suradnici (6) prijavili su $93 \%$ podudarnosti.

Kad je riječ o podudarnosti između ispitanika, dobivene vrijednosti bile su u skladu s Pinchijem i suradnicima (6) kod kojih je ona iznosila $90 \%$.

Jedan od glavnih ciljeva ovoga rada bio je analizirati postoje li uočljive razlike između kronološke i procijenjene dobi. Za metodu procjene odabran je Atlas Al-Qahtanija (25) jer su u usporedbi $s$ drugim takvim metodama njime postignuti najbolji rezultati bez pristranosti $(\mathrm{p}=0,720) \mathrm{s}$ ispravnom procjenom u $53 \%$ slučajeva $(16,25)$.

U ovom istraživanju rezultati su pokazali da je bilo nekih pogrešaka u procjenama i za DS i za LS. Za usporedbu su korišteni rezultati Cesárija i suradnika (16), Pavlovića i suradnika (26) i Pinchija i suradnika (6). Test performansi pokazao je statistički značajnu razliku između procijenjene i kronološke dobi. Čini se da su procjene dobivene na objema stranama bile pristrane, tj. učinjena je sustavna pogreška (desno: autor $\mathrm{p}=0,000$; Pavlović $\mathrm{p}=0,104$; lijevo: autor $\mathrm{p}=0,000$; Pavlović $\mathrm{p}=0,052)$. Prema tome, ti rezultati nisu u skladu $s$ onima Pavlovića i suradnika (26), no moramo imati na umu da je glavna razlika između tih istraživanja bila populacija. Uz to, pogreška je između strana bila konzistentna i nije uočena značajna razlika između procjene dobi na DS-u ili LS$\mathrm{u}$ (autor $\mathrm{p}=0,864$; Pavlović $\mathrm{p}=0,066$ ). $\mathrm{U}$ ovom radu dob je maksimalno podcijenjena za 123 mjeseca (Pavlović 91 mjesec), a maksimalno precijenjena za 67 mjeseci (Pavlović 79 mjeseci) (26).

Drugi glavni cilj bio je analizirati postoje li razlike između dobnih skupina ispod i iznad 16 godina (m 16 u odnosu prema M 16). U objema je u ovom istraživanju postojala tendencija podcjenjivanja, iako su Al-Qahtani (25) i Cesário i suradnici (16) zaključili suprotno. Prosječna pogreška podcjenjivanja u dobnoj skupini $\mathrm{m} 16$ bila je mnogo manja negoli u dobnoj skupini M 16 (0,75 mjeseci desno i 0,37 mjeseci lijevo za m 16 i 26,10 mjeseci desno i 26,79 mjeseci lijevo za M 16), iako je razlika između strana bila gotovo zanemariva (6 ). Nadalje, dobiveni rezultati otkrivaju da nije bilo dokaza da se medijan procjena razlikuje od medijana kronološke dobi u dobnoj skupini mlađoj od 16 godina (desno: autor $\mathrm{p}=0,532$; Pavlović $\mathrm{p}=0,000$; lijevo: autor $\mathrm{p}=0,859$; Pavlović $\mathrm{p}=0,000$ ), a u skupini $\mathrm{M} 16$ razlika se čini značajnom (desno: autor $\mathrm{p}=0,000$; Pavlović $\mathrm{p}=0,105$; lijevo: autor $\mathrm{p}$ $=0,000$; Pavlović $\mathrm{p}=0,161)$. Stoga su autori dobili suprotne rezultate za te dobne skupine. To se može objasniti činjenicom da su populacije bile različite, a kada se uključe i pacijenti $s$ usporenim razvojem zuba, procjenom bi se mogla dodatno podcijeniti dob. Zato se pretpostavlja da je u slučajevima u kojima je dob precijenjena taj problem manje izražen, a u kojima je dob podcijenjena problem je izraženiji. Zbog rezul- 
underestimate age. It is therefore expected that when there is an overestimation, this problem is lower, while if there is an underestimation, the problem is even more serious. Due to the results obtained in the m16 and M16 groups, we have decided to perform a separate analysis wherein the sample was divided into different age groups. Out of these, in the under 6 and 7 to 12 year- old groups, the estimates were unbiased with a trend towards overestimation. However, the age groups of 13 to 16 years of age and above 17 years of age, the estimates were biased with a trend towards underestimation.

\section{Conclusions}

From the results obtained in this study the following conclusions, related to the formulated experimental hypotheses, can be drawn: Chronological versus estimated age: there were statistically significant differences, revealing that the estimates using the Atlas of AlQahtani are biased in the population with special needs. The difference between under (m16) and over (M16) 16 years of age: the estimation error in M16 is significant and much higher than in $\mathrm{m} 16$ where the estimation errors are not significant. Moreover, the use of the obtained estimates to identify individuals younger than 16 years old reveals a good accuracy. Thus, the Atlas of AlQahtani can be used as a method in age estimation for legal purposes, but with caution towards the 16-year threshold. There were no statistically significant differences in the accuracy of the estimates obtained using the left side and the right side. The choice of side is, therefore, irrelevant. There were no statistically significant differences in the accuracy of the estimates between genders. It seems, therefore, that the same atlas can be used for both genders. When the sample was divided into with and without dental repercussions: those persons with systemic diseases with dental manifestations had a much higher error in underestimation. Therefore, the midpoint in these cases should be clearly enlarged for persons with Down's syndrome, chromosomic alterations, syndromes and central nervous system disorders. As for those without dental manifestations, the midpoint should also be reassessed in some ages, but the correction will not be significant.

Hence, there was a general prevalence for underestimation, except for the age groups of under the age of 6 and 7 to 12 . We also confirm the fact that it is easier to classify and estimate age in patients under 16 than over 16 years of age. As these types of subjects tend to move moderately during the radiological examination, it would be of great value that the OPGs are of high quality. If possible, the use of CBCT, which provides better imaging, is recommended. Regarding the sample size, some of the groups analyzed had a very low number of subjects; therefore the conclusions that could be drawn were suggestive and preliminary. We suggest further research with larger international samples to create adequate atlases for all the required scenarios, mainly, charts for persons with systemic diseases aged approximately 16 . tata dobivenih u skupinama m 16 i M 16, odlučili smo se na zasebnu analizu u kojoj je uzorak podijeljen u različite dobne skupine. Od toga su u skupinama mladih od 6 i 7 do 12 godina, procjene bile nepristrane $s$ tendencijom precjenjivanja. No u dobnim skupinama od 13 do 16 i starijih od 17 godina, procjene su bile pristrane, $s$ tendencijom podcjenjivanja.

\section{Zaključci}

Iz rezultata dobivenih u ovom istraživanju može se zaključiti sljedeće $u$ vezi s predloženom eksperimentalnom hipotezom: kronološka dob u odnosu prema procijenjenoj dobi: postoje statistički značajne razlike koje otkrivaju da su procjene nakon korištenja Al-Qahtanijeva Atlasa pristrane u populaciji s posebnim potrebama; razlika između skupina mlađih (m 16) i i starijih (M 16) od 16 godina: pogreška procjene $u$ skupini M 16 bila je dosta značajna i mnogo veća negoli u m 16, gdje nije bila značajna; nadalje, korištenje dobivenih procjena za identifikaciju osoba mlađih od 16 godina pokazuje dosta veliku točnost; zato se Al-Qahtanijevim Atlasom možemo koristiti kao metodom procjene dobi u pravne svrhe, ali s oprezom prema granici od 16 godina; nema statističke značajne razlike u točnosti procjena na lijevoj i desnoj strani, pa izbor strane nije važan; nema statistički značajne razlike u točnosti procjene među spolovima: zato se čini da se istim Atlasom možemo koristiti za oba spola; kad je uzorak podijeljen na stanje s posljedicama i bez posljedica na zube, kod osoba sa sistemskim bolestima sa zubnim manifestacijama, pogreška u obliku podcjenjivanja bila je mnogo veća; stoga bi se trebala posvetiti pozornost slučajevima s Downovim sindromom, kromosomskim promjenama, sindromima i poremećajima središnjega živčanog sustava; kad je riječ o onima bez zubnih manifestacija, sredinu bi također trebalo preispitati u nekim dobnim skupinama, ali korekcija neće biti toliko značajna.

Dakle, postojala je opća tendencija podcjenjivanja dobi, osim u dobnim skupinama mladima od 6 i od 7 do 12 godina. Također se pokazalo da je lakše klasificirati i procijeniti dob pacijenata mladih od 16 godina negoli onih starijih od 16 godina. Budući da su ti ispitanici umjereno nemirni tijekom rendgenskog snimanja, važno je da su ortopantomogrami kvalitetni, a ako je moguće, dobro je koristiti se CBCTom koji daje bolje prikaze. $S$ obzirom na veličinu uzorka, u nekima od analiziranih skupina bio je vrlo mali broj slučajeva, pa su zaključci sugestivni i preliminarni. Predlažemo daljnja istraživanja na većim međunarodnim uzorcima kako bismo stvorili adekvatne atlase za sve potrebne situacije, uglavnom dijagrame za osobe sa sistemskim bolestima približne dobi od 16 godina. 


\section{Conflict of interest}

The authors report no conflict of interest

\section{Acknowledgments}

Fundação Nacional para a Ciência e a Tecnologia, Portugal (FCT) under the project UID/MAT/00006/2019.

\section{Sukob interesa}

Autori nisu bili u sukobu interesa.

\section{Zahvale}

Velika hvala portugalskoj Zakladi Nacional para a Ciência e a Tecnologia (FCT-u) za projekt UID/MAT/00006/2019.

\section{Sažetak}

Uvod : Forenzička procjena kronološke dobi sve je važnija u identifikaciji trupala, ali i živih pojedinaca zbog sve češće imigracije i trgovine ljudima bez dokumenata. Cilj: Željelo se validirati već postojeći atlas mineralizacije i erupcije zuba kod normalne djece i adolescenata za procjenu kronološke dobi mlade populacije s posebnim potrebama, uglavnom sa sistemskim bolestima. Materijal metode: Iz dviju neovisnih medicinskih ustanova prikupljen je uzorak od 163 ortopantomograma od 133 pacijenta u dobi od 4 do 23 godine. Podijeljeni su u dvije skupine - prvu u kojoj je bilo 95 pacijenata sa sistemskim bolestima koje ostavljaju posljedice na razvoj zuba i drugu od 68 pacijenata sa sistemskim bolestima bez posljedica na zube. Dentalna dob procijenjena je na temelju Londonova atlasa na lijevoj strani maksile, a zatim neovisno i na desnoj. Izračunate su i analizirane razlike između procijenjene i kronološke dentalne dobi i apsolutne vrijednosti. Rezultati: Dobivene su statistički značajne razlike između procijenjene i kronološke dobi, no uočen je opći trend podcjenjivanja, osim za ispitanike mlađe od 12 godina. Ipak, podcjenjivanje dobi kod mlađih od 16 godina nije bilo značajno (prosječno manje od jednog mjeseca), ali je bilo prilično za one starije od 16 godina (u prosjeku više od 26 mjeseci). Nadalje, za osobe sa sistemskim bolestima koje ostavljaju posljedice na zubima dobivena je veća pogreška u podcjenjivanju, što upućuje na to da bi se srednje vrijednosti trebale preispitati kod osoba s Downovim sindromom, kromosomskim promjenama, sindromima i poremećajima središnjega živčanog sustava. Zaključak: Ovaj Atlas može se upotrijebiti za procjenu dobi u populaciji s posebnim potrebama sa sistemskim bolestima, ali predlažemo daljnja istraživanja s većim međunarodnim uzorkom kako bi se stvorili odgovarajući atlasi za sve potrebne situacije, uglavnom dijagrami za oboljele od sistemskih bolesti starije od 16 godina.
Zaprimljen: 8. listopada 2019. Prihvaćen: 1. prosinca 2019.

Adresa za dopisivanje Cristiana Palmela Pereira University of Lisabon School of Dental Medicine Rua Professora Teresa Ambrósio, 1600-277 Lisboa, Portugal. cristiana.pereira@fmd.ul.pt

\section{Ključne riječi}

određivanje dobi s pomoću zuba; djeca s invaliditetom; nicanje zubi; kalcifikacija zubi; adolescent

\section{References}

1. Pereira CP, Escobar CP, Santos, JC. Age Estimation of Unaccompanied Minors: A Portuguese Overview. Annals of Forensic Research and Analysis, 2015;2(1):1012.

2. Oliveira CR, Gomes N. Indicadores de Integração de Imigrantes Relatório estatístico Anual. [serial on the Internet]. 2017. Available from: http://www.om.acm.gov.pt/documents/58428/383402

3. Ribeiro MJ, Estrela J, Machado, R. Relatório de Imigração, Fronteiras e Asilo. [serial on the Internet]. 2017. Available from: https://sefstat.sef.pt

4. Sykes L, Bhayat A, Bernitz H. The Effects of the Refugee Crisis on Age Estimation Analysis over the Past 10 Years: A 16-Country Survey. Int I Environ Res Public Health. 2017 Jun 13;14(6).

5. Anastácio AC, Serras C, Vargas de Sousa SRF, Palmela Pereira C. Validation of Cameriere's medical-legal age estimation method using seconds premolars in a Portuguese population. J Forensic Leg Med. 2018 Nov;60:30-34.

6. Pinchi V, Bugelli V, Vitale G, Pradella F, Farese L, Focardi M. Dental age estimation in children with chromosomal syndromes. J Forensic Odontostomatol. 2018 May 30;36(1):44-52.

7. Galić I, Nakaš E, Prohić S, Selimović E, Obradović B, Petrovečki M. Dental Age Estimation Among Children Aged 5-14 Years Using the Demirjian Method in Bosnia-Herzegovina. Acta Stomatol Croat. 2010;44(1):17-25.

8. Garn SM, Lewis AB, Polachek DL. Variability of Tooth Formation. Dent Res. 1959 Jan-Feb;38(1):135-48.

9. Garn SM, Lewis AB, Kerewsky RS. Genetic, Nutritional, and Maturational Correlates of Dental Development. I Dent Res. 1965 JanFeb;44:SUPPL:228-42.

10. Schmeling A, Geserick G, Reisinger W, Olze A. Age estimation. Forensic Sci Int. 2007 Jan 17;165(2-3):178-81.

11. Elamin F, Liversidge HM. Malnutrition Has No Effect on the Timing of Human Tooth Formation. PLoS One. 2013 Aug 30;8(8):e72274.

12. Bagić IC, Sever N, Brkić H, Kern J. Dental Age Estimation in Children Using Orthopantomograms. Acta Stomatol Croat. 2008;42(1):1118.

13. Kvaal SI, Kolltveilr KM, Thomesen IO, Solheim T. Age estimation of adults from dental radiographs. Forensic Sci Int. $1995 \mathrm{Jul}$ 28;74(3):175-85

14. Macha M, Lamba B, Avula JSS, Muthineni S, Margana PGJS, Chitoori P. Estimation of Correlation between Chronological Age, Skeletal Age and Dental Age in Children - A Cross-sectional Study. J Clin Diagn Res. 2017 Sep;11(9):ZC01-ZC04.
15. Popović ZB, Thomas JD. Assessing observer variability: a user's guide. Cardiovasc Diagn Ther. 2017 Jun;7(3):317-324.

16. Cesário C., Santos R, Pestana D, Palmela Pereira C. Medico-Legal Age Estimation in a Sub-adult Portuguese Population: Validation of Atlas Schour and Massler and London. Journal of Civil \& Legal Sciences. 2017;05:196.

17. Willems G. A review of the most commonly used dental age estimation techniques. J Forensic Odontostomatol. 2001 Jun;19(1):9-17.

18. Seagriff-Curtin P, Pugliese S, Romer M. Dental considerations for individuals with Down syndrome. N Y State Dent J. 2006 MarApr;72(2):33-5.

19. Diz P, Limeres J, Salgado AF, Tomás I, Delgado LF, Vázquez E, Feijoo JF. Correlation between dental maturation and chronological age in patients with cerebral palsy, mental retardation, and Down syndrome. Res Dev Disabil. 2011 Mar-Apr;32(2):808-17.

20. Suri S, Tompson BD, Atenafu E. Prevalence and patterns of permanent tooth agenesis in Down syndrome and their association with craniofacial morphology. Angle Orthod. 2011 Mar;81(2):260-9.

21. de Moraes ME, de Moraes LC, Cardoso M, Ursi W, Lopes SL. Age assessment based on dental calcification in individuals with Down syndrome. Res Dev Disabil. 2013 Nov;34(11):4274-9.

22. Patil S, Rao RS, Majumdar B. Chromosomal and Multifactorial Genetic Disorders with Oral Manifestations. Journal of International Oral Health. 2014; 6(5):118-125.

23. Cuoghi OA, Topolski F, Perciliano de Faria L, Occhiena CM, Ferreira ND, et al. Prevalence of Dental Anomalies in Permanent Dentition of Brazilian Individuals with Down Syndrome. J Int Oral Health. 2014 Sep;6(5):118-25

24. Braz P, Machado A, Dias CM. Ministério da Saúde - Registo Nacional de Anomalias Congénitas: INSA-IP Lisboa. [serial on the Internet] 2014/2015. Available from: http://repositorio.insa.pt/bitstream $/ 10400.18 / 5382 / 5$

25. AlQahtani, SJ. The London Atlas : developing an atlas of tooth development and testing its quality and performance measures. [serial on the Internet] 2012. Available from: http://qmro.qmul. ac.uk/jspui/handle/123456789/3363

26. Pavlović S, Pereira CP, Santos R. Age estimation in Portuguese population: The application of the London atlas of tooth development and eruption. Forensic Sci Int. 2017 Mar;272:97-103.

27. Fleiss JL. The design and analysis of clinical experiments. Wiley, 1999. pp. 228-242. 